\title{
The Italian Occupation of the Balkans and the Jewish Question during WWII
}

\author{
M. Clementi
}

For citation: Clementi M. The Italian Occupation of the Balkans and the Jewish Question during WWII. Vestnik of Saint Petersburg University. History, 2018, vol. 63, issue 1, pp. 174-186. https://doi. org/10.21638/11701/spbu02.2018.112

With the entry into the war in 1940, first against France, then against Greece and Yugoslavia, Italy tried to realise its old expansionist plans in the Balkans to control the Adriatic Sea and the South part of Mediterranean, replacing the British power. In the annexed and military occupied territories Italy established a harsh regime, which has only come to public conscience in recent years, after decades of silence. At the same time, Italian generals had to face a brand new problem, concerning thousands of Jews, local and foreign, who escaped to Italian zones in France, Yugoslavia and Greece from the zones under German, Croatian and Bulgarian control. In 1942 Mussolini was aware of the destiny which awaited the Jews after the deportation; in spite of this, he agreed to surrender them to the partners of the Axis. In Mussolini's opinion, any country that dreamed of being a great power in the future was suppose to have have its own racial policy. From this perspective, he was convinced that Italy should be "clean" of Jews in order to be ready for the new era after the war. The Army "on the ground" refused to follow the orders and found a way to avoid mass deportation to the death camps (Venrichtungslager), and only with its defeat in September 1943, Germany and Mussolini could act freely, completing the destruction of the Jews in North Italy and in the former zones of military occupation. In this context, the deportation of the Jews happened not only because of German occupation, as many scholars still maintain, but because of the previous policy established by Mussolini during WWII.

Keywords: Second World War, occupation, Jews, Italy, Greece, Yugoslavia, Balkans.

\section{Итальянская оккупация Балкан и еврейский вопрос во время Второй мировой войны}

\section{М. Клементи}

Для цитирования: Clementi M. The Italian Occupation of the Balkans and the Jewish Question during WWII // Вестник Санкт-Петербургского университета. История. 2018. Т. 63. Вып. 1. C. 174-186. https://doi.org/10.21638/11701/spbu02.2018.112

После вступления в войну в 1940 г. сначала против Франции, затем против Греции и Югославии Италия попыталась реализовать свои старые экспансионистские планы на Балканах с целью контролировать Адриатическое море и южную часть Средиземного моря, где надеялась заменить Британскую державу. На оккупированных территори-

Clementi Marco - PhD, Associate Professor, University of Calabria, Cubo 0B, via Pietro Bucci, Rende (CS), 87100, Italy; marco.clementi@unical.it

Клементи Марко - PhD, доц., Университет Калабрии, Италия, 87100, Ренде, ул. Пьетро Буччи, Кубо 0B; marco.clementi@unical.it

() Санкт-Петербургский государственный университет, 2018 
ях Италия установила жесткий режим, который начал анализироваться в историографии лишь недавно, после десятилетий молчания. Итальянским генералам пришлось столкнуться и с проблемой, касавшейся тысяч евреев, местных и иностранных, которые бежали в итальянские зоны оккупации в Югославии и Греции из зон, находившихся под контролем немцев, хорватов и болгар. В 1942 г. Муссолини узнал о судьбе, которая ждала евреев после депортации; несмотря на это, он согласился передать их своим союзникам. По мнению Муссолини, любая страна, которая мечтала стать великой державой в будущем, должна была иметь свою собственную расовую политику. С этой точки зрения он был убежден, что Италию нужно очистить от евреев и таким образом готовиться к новой эре после войны. Несмотря на приказы дуче, итальянская армия не дала своим военным партнерам возможности массовой депортации евреев в лагеря смерти. Только после ее поражения в сентябре 1943 г. Германия и Муссолини смогли действовать свободно, завершив уничтожение евреев в Италии и бывших зонах ее военной оккупации. Депортация евреев происходила не только из-за немецкой оккупации Италии, как еще думают многие ученые, но также из-за политики, установленной Муссолини во время Второй мировой войны.

Ключевые слова: Вторая мировая война, оккупация, евреи, Италия, Греция, Югославия, Балканы.

The persecution of the Jews in the Italian-occupied and Italian-annexed territories during the interwar period and WWII has to do not only with the behavior of the Italian soldiers, but with the entire Italian political and military system from 1938 up to the end of the war. The problem doesn't concern only the extent of racism of the fascist government, but also the Italian strategy towards the Jewish question. It would be desirable to reconstruct facts and understand when and whether Mussolini's regime conceived of a clear strategy; when and whether Italian authorities allowed the deportation of Jews from the areas of their military control; it would be also interesting to survey Italian relationships with local political authorities vis-à-vis the Jewish communities and refugees in the areas of occupation. It would be also worthwhile to understand why the end of the war meant the possibility for a collective "auto absolution" for the Italians officers despite the crimes they had committed in the occupied countries ${ }^{1}$.

The scholars, of course, have already given attention to several above mentioned points, but not comprehensively; besides, many works dedicated to the Italian military occupations during WWII are concentrated on the fate of the Italian soldiers after the armistice of 1943, not elaborating on the destiny of the Jews or of the civil population. We can divide the works about the Shoah in Italy and in the zones of Italian military occupation in two groups. In the first one we find the researches dedicated to the deported Italian Jews ${ }^{2}$, to the mechanism and the timing of the deportations $s^{3}$, to the life in the concentration camps ${ }^{4}$, to the bureaucratic organization of the camps ${ }^{5}$ and to the memory $y^{6}$. Some schol-

${ }^{1}$ Giustolisi F. Larmadio della vergogna. Roma, 2004; Conti D. Criminali di guerra italiani. Roma, 2011.

2 Pezzetti M. Il libro della Shoah italiana. I racconti di chi è sopravvissuto. Torino, 2009.

${ }_{3}$ Picciotto L. Lalba ci colse come un tradimento. Gli ebrei nel campo di Fossoli 1943-1944. Milano, 2010.

${ }^{4}$ Pizzuti A. Vite di carta. Roma, 2010.

${ }^{5}$ Capogreco C. S. I campi del Duce. L'internamento civile nell'Italia fascista (1940-1943). Torino, 2004.

${ }^{6}$ Picciotto L. Il libro della memoria. Gli ebrei deportati dall'Italia. Milano, 1991. 
ars studied the condition of the Jews under the fascism and the consequences of the racial laws ${ }^{7}$, the role of the Catholic Church ${ }^{8}$, the relation between fascist culture and genocide ${ }^{9}$.

N. Revelli and G. Bedeschi collected memories of the Italian soldiers, trying to understand their beliefs and hopes, while D. Mack Smith and G. Rochat concentrated their attention on the Mussolini's war. M. T. Giusti wrote about Italian prisoners in the Soviet Union and in the Balkans. B. Mantelli e N. Tranfaglia edited 4 volumes about the deported Italian soldiers after 1943. D. Carpi studied the relations between Mussolini and Hitler and the consequences of the Jewish question in Croatia during the Italian occupation.

As many scholars have pointed out, Eastern Europe was the most relevant spot of the genocide (the region of genocide); by and large, however, the Italian specialists of East European History, with few exceptions, have given little attention to this aspect, which is commonly omitted in the general courses of histories of the countries. As historian Sabina Donati wrote a few years ago, «while there are many pioneering studies about the history of Jews in the Italian peninsula during the Fascist regime, the different and complex stories of Jews in the territories occupied or annexed by Mussolini's Army has yet to be investigated in depth ${ }^{10}$.

With its entry into WWII in 1940 Italy hoped to carry out its old expansionist plans in the Balkans. The main aim of this policy was to "replace" the British power and gain full control over the Mediterranean Sea. Between 1940 and 1942 Italian Army occupied important territories in France, Greece and Yugoslavia. All the conquered zones were divided into annexed and military occupied territories. Croatia, Montenegro and Greece were occupied; the coast of Dalmatia with Split and Ragusa [Dubrovnik] and the province of Ljubljana were annexed. In general, Italy established a harsh regime of occupation, only recently analyzed deeply by a new generation of Italian historians. In 1941, with the attack against the Soviet Union, the Italian Army also occupied a large area of the Ukraine and Russia, between the Black Sea and the Don River, and a part of Belarus. Here the Germans and part of their allies soon began annihilating the Jewish population and, as far as we know, at least in one situation some Italian soldiers, without the permission of their superiors, handed a small group of local Jews to the Germans in Lviv ${ }^{11}$. According to Timothy Snyder, for the Germans such places as Poland and Ukraine were "virgin lands"; the Italians twisted the message, comparing Poland to Ethiopia, a land that had to be colonized ${ }^{12}$. However, the Italian historiography has generally failed to investigate the behavior of the 230, 000 Italian soldiers sent to the USSR to assist the German armies. The memorialization of the Italian campaign in the Soviet Union as well as the historiography seem to have removed this component.

The war brought about immediate and dramatic changes for the Jews living in Italy. In June 1940, when Italy declared war to France and Great Britain, all foreign Jews who had re-

7 Felice R. de. Storia degli ebrei italiani sotto il fascismo. Torino, 2005; Sarfatti M. La Shoah in Italia. La persecuzione degli ebrei sotto il fascismo. Torino, 2005; Matard-Bonucci M. L'Italia fascista e la persecuzione degli ebrei. Bologna, 2008.

${ }^{8}$ Moro R. La Chiesa e lo sterminio degli ebrei. Bologna, 2009; Kertzer D. Il patto col diavolo. Milano, 2014; Zuccotti S. Under his very windows: the Vatican and the Holocaust in Italy. New Haven, 2000.

9 Ben Ghiat R. La cultura fascista. Bologna, 2004.

${ }^{10}$ Donati S. Gli ebrei in Albania sotto il fascismo//Annali della Società Italiana per lo Studio della Storia Contemporanea. URL: http://www.sissco.it/recensione-annale/laura-brazzo-michele-sarfatti-a-cura-di-gli-ebrei-in-albania-sotto-il-fascismo-una-storia-da-ricostruire-2010) (accessed 15.12.2017).

11 Rochat G. Leopoli 1942-1943. Militari italiani dinanzi alla Shoah // La rassegna mensile di Israele. 2003. Issue 2. P. 387-394.

12 Snyder T. Black Earth: The Holocaust as History and Warning. London, 2015. P. 142. 
mained in Italy after the expulsions of 1938-39, were sent to concentration camps and in various centres of internment. Very soon, to those groups were added foreign Jews, who entered the territories controlled by the Italian Army, trying to escape from Germany, from its allies in Central Europe and in the occupied Poland. During 1941-1942 Italy closed the borders and approximately 9.800 foreign Jews were sent to the concentration camps in Italy (e.g. Ferramonti in Calabria), while several thousands were interned in Yugoslavia, Albania and Libya.

By early spring 1943 most of the Jewish communities in East Europe had already been destroyed ${ }^{13}$. An internal report compiled by Himmler's Reich Inspector of Statistics, Richard Korherr, claimed that by this date European Jewry had been reduced to half of its prewar number. Of the remaining population, the majority was concentrated in the countries of Central and South Europe ${ }^{14}$. As far as we know, Bulgaria and Romanian didn't protect foreign Jews living in the areas under their control: as R. Hilberg wrote, Bulgarian government "gave up the Jews of the freshly acquired regions in Macedonia, Thrace and Pirot but resisted deportations from Old Bulgaria". Romania, after having recovered Northern Bukovina and Bessarabia from the Soviet Union in 1941, "promptly expelled the Jews from these provinces"15. In contrast, in 1941-1943 Italian authorities displayed ambivalence towards Berlin's requests to implement a wholesale genocidal policy. This attitude affected all Jewish population and showed Italian sensitivity to the issue of national sovereignty. In some cases it also reflects, among other factors, the desire of the Italian authorities to distinguish the position of the so-called Major Power from the Minor Powers. As we will see, however, it is not fully correct that Mussolini's government wanted to make clear that Italy was able to handle the Jewish question only for the sake of its own interest. It is true that the Italian authorities reserved their own right to establish a hierarchy among the Jews, who were allowed to transit through the peninsula or admitted into the Italian-controlled territories and that only after Italy's capitulation in September 1943 a systematic deportation to the death camps took place in areas once occupied by the Italian Army (and now free of it) in Southern France, Yugoslavia, Greece. At the same time, the Italian government, and namely, Mussolini himself, already in 1942 decided to give up all the foreign Jews under Italian control, and only the resistance of the Italian Army, engaged "on the ground", stopped this act. We find an exception to this dualism only in Kosovo, part of the Albania at that time; here in March 1942 the Italian authority gave up to the Germans a group of Serbian Jews fleeing from Belgrade. A second group of Jews, ready to be delivered to the Germans, was stopped by the Albanian government, which transferred the Jews to old Albania ${ }^{16}$.

According to E. Benbassa and A. Rodrigue, during WWII the Italian soldiers acted in an adequate way in their zones of occupation, saving many Jewish lives. Being allied with the Germans, they did not accept the policy of deportation and tried everything which was in their power to avoid it. The motive for this behavior should be found in a congenital humanistic Italian spirit, in a lack of confidence regarding Germany, in a relative freedom of action in the Army and in a long tradition of disrespecting the orders, mostly for fear of public opinion. All those elements together - as the scholars assume - made up

13 Yahil L. The Holocaust. The Fate of European Jewry. Oxford, 1990.

14 Dimension der Völkermords. Die Zahl der jüdischen Opfer des Nationalsozialismus / Hrsg. von W. Benz. München, 1991.

${ }^{15}$ Hilberg R. Perpetrators Victims Bystanders. The Jewish catastrophe 1933-1945. New York, 1993. P.77-78.

16 Sarfatti M. Tra uccisione e protezione. I rifugiati ebrei in Kosovo nel marzo 1942 e le autorità tedesche, italiane e albanesi // La rassegna mensile di Israel. 2010. Issue 3. P.223-242. 
a new situation, in which the main European partner of the Nazi regime - Italy - could even suspend for some time the "final solution"17. The problem itself, of course, cannot be solved by simply evaluating how good or bad Italian soldiers were. This matter is not so interesting, fist of all because the historiography doesn't give moral or ethical answers but tries to understand the motives behind the choices. Moreover, the Italian soldier could not decide anything. As N. Revelli showed, he could hardly write or read, hardly understand the meaning of the war and didn't distinguish a Jew from an Albanian or a Turk ${ }^{18}$. Only in the political and military hierarchic chains do we find the meaning of the decisions taken by the Italians concerning the Jews. And this meaning was so ambivalent that before September 1943, a Jew who had to do with the Italians could not be sure of his own destiny: he could be saved, killed, stopped at the Italian borders or deported. It depended on many different and apparently not always connected with each other circumstances.

The main phases of the occupation of Greece and Yugoslavia are already well known. In general, the Italian intervention in those countries aimed at the realization of a New Mediterranean Order ${ }^{19}$. There were no clear and coherent indications of it, but some different elaborations, sometimes ambiguous and in contradiction with each other, which appeared on the tables of Italian High Commander between 1938 and 1941. In this context, the annexation of the Ionic Island and the Cyclades, on the one hand, would have blocked the access to the Adriatic Sea for the potential enemies, on the other hand, extended the Italian control over the Levant by annexing Syros to the Dodecanese, the Aegean Islands under the Italian rule since $1912^{20}$. Dalmatia would have connected Italy and Albania, just set by Italians in 1939, so that the coast of the Adriatic Sea would have been taken under control by Rome.

In May 1941 in Greece, almost immediately after the occupation, an Italian official of the Ministry of Foreign Affairs, Piero Parini, was appointed civil governor of Corfù; he began a large-scale italianization of the Ionic Island, introducing a new Italian postal service and the Ionic lira in addition to the Drachma, which was beginning to lose its value because of a wide economic crisis that took place in Greece ${ }^{21}$. An Italian war hero of WWI, Colonel Giovanni Duca, was placed in charge of the 16 Islands of the Cyclades. His duty was to organize the distacco [separation] of the Cyclades from Greece and to annex them to Rhodes. Nevertheless, none of the two plans was realized. The sheme of Parini, thanks to the introduction of the Ionic lira, went forward but provoked the reaction of the quisling Greek government in Athens and of the Germans. On the Cyclades Colonel Duca, acting in accordance with the governor of Rhodes, Admiral Inigo Campioni, could not even begin the distacco from the administrative point of view, operating only in the field of economy to make up a "close economic circuit" between Syros and Rhodes. For instance, on 20 June 1941 any export to Athens was forbidden, and new taxes on houses, professions, properties, incomes, alcohol, revenue stamps, cars and bicycles, telephone and telegraph and so on were introduced. The distacco, planned at the beginning of Feb-

17 Benbassa E. Rodrigue A. Storia degli ebrei sefarditi. Torino, 2002. P.279-280 (original - Histoire des Juifs sépharades. Da Tolède à Salonique. Paris, 2002, 408 p.).

${ }_{18}$ Revelli N. La guerra dei poveri. Torino, 1962. Passim.

19 Rodogno D. Le nouvel ordre fasciste en Méditerranée, 1940-1943: présupposés idéologiques, visions et velléités // Revue d'histoire moderne et contemporaine. 2008. Issue 55, 3. P.138-156.

${ }^{20}$ Lecoeur S. Mussolini Greek's Island. Fascism and the occupation of Syros in World War II. London, 2009.

${ }^{21}$ Clementi M. Camicie nere sull'acropoli. L’occupazione italiana della Grecia. Roma, 2013. P. 68. 
ruary 1942, was delayed until March, then April and, finally, till the next year ${ }^{22}$. The Italian policy in the Cyclades had a negative impact. The industry lost productivity owing to the lack of fuel and raw material, and the navigation went down because of the destruction of the fleet. Syros, the third port of Greece, lost its importance and plunged into crisis. When it became harder for Italy to take control of the sea because of the defeat in Africa, the Cyclades experienced food shortage, with dramatic consequences for the civil population. Between the end of 1941 and 1943 the mortality rate on Syros and on other islands rose six times, compared to pre-war period, which was definitely not easy for Greece ${ }^{23}$.

More generally, the Italian occupational policy meant a discontinuity in the Greek history, dividing the country in several economic zones, confined and isolated from one another. When the real drama showed itself, the Italians tried to help the civil population in coordination with the Red Cross and the Greek quisling authorities in Athens, but the results were not always adequate. As we can see, Italians were executioners and rescuers (to make it simple) at the same time, and the complexity of the occupation constantly forced them to face new responsibilities, in many cases against their will ${ }^{24}$.

One of those responsibilities, which probably Italians didn't expect, was to handle thousands of Jews, local and foreign, which - with the progress of the war and the evolution of the German policy against them - became more and more important. Italy kept a dual position, in Greece and outside it.

In Northern Greece, occupied by German army in April 1941, anti-Jewish measures were fist taken on February 6, 1943, when all Jews of Salonica were forced to register at the Gestapo headquarters. Between 15 and 28 February they were constrained to wear the star of David and the registration number. In early March they were concentrated in the notorious ghetto named "Baron Hirsh", where they lived in precarious sanitary conditions, and on March 14 their deportation to Poland began. Non-Jewish citizens couldn't take care of, or acquire properties left behind by the Jews, which were eventually confiscated. The concentration and deportation of all Jews in the rest of Macedonia began at the same time as that of the Jews of Salonica. According to a record of 1947, the first deportation was limited to Macedonia because the Italians, who occupied almost all the rest of Greece "ne permettaint pas aux Allemands de mettre en pratique leurs méthodes de persécution; au contraire, les autorités italiennes de la Grèce du sud, où je me trouvais moi même, nous ont beaucoup aidés et les Allemands nont pas appliqué les mêmes méthodes"25. A few months later, during a meeting that took place in Rome on August 30th, the Italian plenipotentiary representative in Athens, Pellegrino Ghigi, warned the government that the Germans would soon be able to declare the whole Greece their military area and to assume full power, ousting the Greek government. Therefore, Italy had to take counter-measures to save as many lives as it was possible. The first issue concerned the assistance of the

22 State Archive of the Cyclades, Greece (GAK ANK). Fak. 45. Allilografia me Comando Superiore Forze Armate, Comando militare delle Cicladi, Distacco amministrativo isole greche occupate. Sira 6 marzo 1942. Duca.

23 GAK ANK. Fak. 20. Verbale di Consegna, Sira 27 giugno 1942, f.to il comandante militare delle Cicladi e reggente la prefettura Cicladi, cessante, colonnello Giovanni Duca e il Commissario civile, subentrato, cons. gen.le Valerio Valeriani. Allegato E. L. 7.

${ }^{24}$ Loukos Ch. Thanatoi apo peina sti Siro 1941-1944. Mithoi kai pragmatikotites // Deltio Kentrou tis Istorias tou Neoterou Ellinismou. Mnimi Eleutheriou Prevelaki. Athina, 1998.

${ }^{25}$ Istoriko Archeio tuo Ypourgeiou Exoterikon (IAYE), Archeio Istorias Ellinon Evraion. Fak. 5. Ipofak. 7. Centrale de Documentation Juive, New York 29-30 novembre 1947. L. 2-3. 
Jews «especially those of Italian nationality». They had been already moved to Athens in order to be protected from the racial measures adopted by the Germans, and Ghigi suggested that they should be transferred to Italy or, at least, to the Ionian Islands ${ }^{26}$. The plan never materialized and it is not clear why Ghigi tried to draw the attention of the Italian government to the Jewish plight so late, and only several days before the capitulation ${ }^{27}$.

In 2007 Massimo Pera, writing the review of a book edited in collaboration with the Italian Embassy in Athens, said that when the Italian Army saved 350 Italians Jews from the deportation in 1943, it was done for several reasons, but not due to "humanism". The first reason was an economic one. The Italian Jews of Salonica were very rich and saving them meant the protection of the Italian economic interests in that town. The second reason involved political and diplomatic arguments: the Italians began the war against Greece, but the Germans controlled the most important economic and strategic zones of the country. Resisting the requests concerning the Jews, Italian Army tried to show independence and autonomy to Berlin ${ }^{28}$. Indeed, the Galeazzo Ciano's orders in this sense were very clear and speaking to the officers in charge in Greece he said that "Italian citizen of Jewish race $\langle\ldots>$ should be defended not because they are Jews, but because they are Italian citizens". M. Pera doesn't see "anything human" in those instructions, but orders given to emphasize Italian power and autonomy.

The behavior of the Italian authorities, extremely sensitive to issues of sovereignty, reflects - as we have said before - their will to distinguish the position of Italy from the countries that Germany considered subordinate. Rome made clear that Italy - like Germany - had the right to handle the Jewish question according to its own interests and not as byproduct of a German point of view. They reserved the right to establish their "own hierarchy" among the Jews who were allowed to transit through the peninsula.

In the Dodecanese, which comprised Italian territories at the time but geographically was far from Rome, the situation changed only after September 1943, when the Germans occupied the island. Then, in a few months, with the full collaboration of the Italian administrative authorities, the Germans deported the entire local Jewish community, which became the largest deportation from an Italian territory in a single day (around 1850 people, 151 survivors). As it is now well known, thanks to the documents found in Rhodes in the Royal Carabineers Archive (a collection closed for seven decades in a basement of the former barracks of the Carabineers in Rhodes and brought to light in December 2013 by an Italian researcher in collaboration with the local Historical State Archive), it has been possible to reconstruct the dynamics of deportation from the Italian side: in April 1944 Italian authorities prepared a list in two copies with all the Jewish families living on the Island at the time; in May they gave one copy to the SS officers Friedrich Linnemann and Anton Burger, who was in charge of the deportation on the German side ${ }^{29}$. In April 2014 an original copy of the list was found containing the names of 1660 Jews of Rhodes

${ }^{26}$ Archivio Storico Ministero Affari Esteri (ASMAE). Gabinetto del ministro e della segreteria generale 1923-1943. Serie V. Grecia Ufficio Armistizio Pace. B 1486 (1-AP21). Situazione Grecia AG Grecia PG, Minutes of the inter ministerial meeting held at the Ministry of Foreign Affairs 30 August 1943 on the situation in Greece.

27 Sarfatti M. L'evacuazione nel 1943 da Salonicco degli ultimi ebrei italiani e degli ebrei italiani 'provvisori': contesto, questioni e numeri / eds P. Ioly Zorattini, M. Luzzati, M. Sarfatti. Firenze, 2012. P.251-276.

28 Pera M. Ebrei di Salonicco. Appunti su "l'umanità italiana" // Studi Storici. 2007. Vol. 48, issue 2. P. 352-353.

${ }^{29}$ McElligott A. The last transport. The Holocaust in Eastern Aegean. London, 2018. 
(to them one should add circa 100 people not registered by the Italian authorities and circa 90 Jews deported from the nearby island of Cos). Since the Jewish quarter in the Old Town of Rhodes was seriously damaged in February and April 1944 after the bombing by the British Air Force, most of the Jews lived in different places, all over the island, and the deportation wouldn't have been possible without the full collaboration of the Italian civil authorities, the only body who had all the information about the Jewish community ${ }^{30}$.

In Croatia, another zone of Italian interest, the main race laws were adopted and signed by the Ustaši leader Ante Pavelič on April 30, 1941, but actions against Jews began immediately after the dissolution of the Yugoslavia and the foundation of the Independent State of Croatia. On 10-11 April 1941 a group of prominent Jews in Zagreb was arrested and held for ransom. When a larger deportation began, some months later, the II Italian Army had already occupied the coast of Dalmatia, where about 3000 Jews of different nationalities (from different regions) lived in bad conditions. A year later, Germans and Croatians asked the Italians to give up the refugees. What was the consequence of this action? How did it affect the situation in Croatia?

To answer the questions, one should state that all the political decisions directly regarding the destiny of the Jews under Italian control (foreign or Italian), were taken personally by Mussolini, without exceptions; secondly, we know for sure, that in 1942 Mussolini was already aware of the destiny of the Jews, once "moved to East" - that is deported to Poland to be killed. For the Duce the decision-making process was cumulative and long, but not impersonal. He was well informed about the evolution of the German's decisions; for instance, in June 1941 Hitler referred to him in connection with Franz Rademacher's "Madagascar Project", which was a plan popular in Poland in $1937^{31}$. According to Ch. Browning, the German policy also affected the Italian migration policy versus (concerning) the Jews; Rome modelled its decisions on the Nazi's escalation, trying only later to show a certain level of autonomy ${ }^{32}$. Between 1933 and 1939, 215.200 people emigrated to Palestine, and after 1938 the majority of them tried to do it by the sea. The departure points were located all over the Mediterranean Sea in ports like Fiume, Trieste, Piraeus and Costanța. Usually the routes went through the Aegean Sea and, in particular, through the Dodecanese, which was already an important stopover for the travellers to Palestine. In order to deal with the situation, Italian authorities reacted in different ways. Sometimes they permitted the refugees to cross the borders to embark, but on other occasions they stopped the refugees. In the Dodecanese the Italian Navy helped the ships experiencing difficulty only once, in the case of the notorious "Pentcho"; most of the time the ships were always forced to continue the journey, even in precarious conditions and without the opportunity to have a rest in a port ${ }^{33}$.

Between September and December 1941 the German policy towards the Jews took a new turn, which resulted in the well-known Wannsee Conference. According to Peter Longerich, it was «rather an important stage in the decision-making process that dragged on from the autumn of 1941 to the spring of 1942, in the course of which the leadership of

${ }^{30}$ Gli ultimi ebrei di Rodi. Leggi razziali e deportazioni nel Dodecaneso italiano (1938-1948) / eds M. Clementi, Ei.Toliou. Roma, 2015.

${ }^{31}$ Longerich P. Heinrich Himmler: A life. Oxford. 2012. Passim.

32 Browning Ch., with Matthäus Jürgen. The Origins of the Final Solution: The Evolution of Nazi Jewish Policy, September 1939 - March 1942. Lincoln, 2004.

${ }_{33}$ Clementi M. Istorija koroblja "Pentcho" i sud'ba ego passazhirov // Pravo na Imja: Biografika 20 veka. 2014. N 1. P. 45-50. 
the 'Third Reich' expanded the massacre of the Jews in eastern and southern Europe into a systematic program for the destruction of all the European Jews» ${ }^{34}$.

In September 1941, Hitler decided on the full deportation of the German Jews from the Reich ${ }^{35}$. Not long after that, in October 1941, the Spanish government suggested that all Spanish Jews living in France, some 2000 people, could be evacuated to Spanish Marocco,. When German Foreign Office approved the plan, the Reich Main Security Office (Reichssicherheitshauptamt or RSHA) opposed the request, since at that very moment the German policy was to keep all Jews in Europe, preventing any possibility of their emigration. At the same time Franz Rademacher together with Friedrich Suhr, one man of the Eichmann's Office, were sent to Belgrade seeking a solution to the local Jews and Gipsy ${ }^{36}$.

In this dense interplay of events, on December 10, 1941 the Bishop of Trieste and Capodistria, Antonio Santin, wrote to the Italian General Vittorio Ambrosio, commander of the 2nd Army in Sušak, near Fiume [today Rijeka], asking for humanitarian intervention on behalf of circa 300 Jews residing in the part of Croatia occupied by the Italian Army ${ }^{37}$. He knew that the situation in Croatia was already tragic for those people, and he didn't want it to get worse. General Ambrosio answered six days later that he was already aware of the situation of the Jews and that nothing bad would be done to them ${ }^{38}$.

After having hypothesized the creation of a concentration camp for Jews in Croatia, Italy received an official note from Germans, a document that Mussolini saw on August 21, 1942: "Bismarck has transmitted a telegram - says the note - according to which the Embassy of Germany is required to contact the competent Italian military authorities in Croatia, since they want to implement the measures for a mass transfer of Jews to the Eastern territories also from the areas of our occupation". Mussolini's resolution on this note says: "Nulla Osta (No impediments) - Mussolini" 39 . This document is well known ${ }^{40}$ and there is no doubt that Mussolini agreed to give all the local and foreign Jews under Italian control in Croazia to the Ustaši (i. e. to Germans), being aware that for them it would have meant the death.

If the head of Italian government decided to resolve the question in the worst way for the Jews and asked information about the number and the location of them, the Italian Command "on the ground" showed another point of view. On September 11 Vittorio Castellani, a liaison officer of the Ministry of Foreign Affairs to the $2^{\text {nd }}$ Army, informed Rome that General Mario Roatta, head of the occupation forces in Croatia, was against any change of the situation and the status of the Jews. That was not because Italians were in some way "human" or "showed solidarity and understanding" for the Jews, but because the delivery of those people would have dented the prestige of the Italian army in Croatia. Moreover, it would have frightened the Orthodox population, who feared being handed over to Ustaši. And lastly, the Jews didn’t show any behavior contrary to the Italian inter-

${ }^{34}$ Longenrich P. Goebbels. Torino, 2016. Passim.

35 Browning Ch., with Matthäus Jürgen. The Origins of the Final Solution: The Evolution of Nazi Jewish Policy, September 1939 - March 1942. P. 6.

36 Akten zur Deutschen Auswärtigen Politik 1918-1945. Serie E 1941-1945. Göttingen, 1979. S. 570572.

37 United States Holocaust Memorial Museum Archives (USHMMA). RG-40007. 1994. A. 0013. Records relating to treatment of Jews by Italian and German nationals during the Holocaust 1941-1946. Series 1, Il vescovo di Trieste e Capodistria al Generale Ambrosio, 16 dicembre 1941.

38 Ibid. Ambrosio a Vescovo di Trieste e Capodistria 1941.

39 ASMAE. Affari Politici 1931-1945. Croazia 1943. B. 138. F. 8, Deportazione degli ebrei croati.

40 Steinberg J. All or nothing. The Axis and the Holocaust 1941-1943, New York, 1990. 
ests so far ${ }^{41}$. On September 22, 1942, after meeting and correspondence over the issue, General Roatta wrote to Rome that there were about 3000 Jews under Italian control in Croatia, that they did not act against the Italian interests and that it would have been better for the Italian prestige to save them to any intrusion or request ${ }^{42}$.

As we can see, on the one hand, Mussolini was ready to satisfy the Germans requests; on the other hand, there were functioning officers who understood the danger of such an act. This state of affairs is confirmed by a document dated by October 20 1942, in which Hitler and Ribbentrop were also aware of the consent of the Duce to the deportation of Jews from Croatia. In the same paper, we also read that the Croatians, having taken note of the resistance of the Italian command, would have been satisfied with the deportation of Jews to Italy and the confiscation of their property in Croatia ${ }^{43}$. In another document from the same days posted by M. Sarfatti on his site and originated from the Italian Direzione Generale di Pubblica Sicurezza (General Direction of Public Security), we read: "after the end of Yugoslavia, many Jews from the German occupied zones or Croatia got into our zones to escape from violence and even death. Rome was asked about it and gave them a permission to get into the Italian territory. Now the Police in Ljubljana says that something similar is going on and asks for instruction". The answer, in this case, was: "reject them" 44 . The last document in this context, closely connected with the previous one, is from November 4, when the General of Carabineers Giuseppe Pièche informed Mussolini that all the Croatian Jews already deported by the Ustaši, had been killed with the gas on the trains where they were loaded for the transportation to the East ${ }^{45}$.

It is important to emphasise the political position of Mussolini with regard to the Jewish question. The Duce decided the fate of the Jews controlled by the Italians, that is to give them up to the Germans, being aware of their destiny, including the way they would be eliminated. The deportations of the Jews from Italy, which followed the defeat of the Italian Army after September 1943, were not improvised and should be placed within a context in which Mussolini played the main role. Since 1942 he had met the German demands and only the resistance of some high officers could slow down the course of the events.

The action of a group is not the result of the sum of individual beliefs, or the common sense of its members. In the Italian army the hierarchy was solid and recognized, and the chain of command very clear, crumbling only after the armistice of $1943^{46}$. The racial laws represent, in our case, the main frame in which the behavior of the Italian policy and army must be placed. When racial laws were published, there were no street protests or

${ }^{41}$ USHMMA. Records relating to treatment of Jews by Italian and German nationals during the Holocaust 1941-1946. Series 1, Castellani a Pietromarchi, Ministero Affari Esteri. Ufficio di Collegamento con il comando Superiore FFAA Slovenia-Dalmazia, 11 settembre 1942.

${ }^{42}$ Ibid. Records relating to treatment of Jews by Italian and German nationals during the Holocaust 1941-1946. Series 1, Ebrei in Croazia. Comando Superiore FFAA Sloveni-Dalmazia (2 Armata). Ufficio Affari Civili, Al Comando Supremo, f.to Roatta, 22 settembre 1942.

${ }^{43}$ Ibid. Records relating to treatment of Jews by Italian and German nationals during the Holocaust 1941-1946. Series 1, Appunto. Ministero degli Affari Esteri. Gabinetto A. P. Croazia, Roma, 20 ottobre 1942; USHMMA, Records relating to treatment of Jews by Italian and German nationals during the Holocaust 1941-1946. Series 1, Appunto visto dal Duce, f.to Pièche, Roma 4 novembre 1942.

44 Ibid. Records relating to treatment of Jews by Italian and German nationals during the Holocaust 1941-1946. Series 1, Appunto. Ministero degli Affari Esteri. Gabinetto A. P. Croazia, Roma, 20 ottobre 1942.

${ }^{45}$ Ibid. Records relating to treatment of Jews by Italian and German nationals during the Holocaust 1941-1946. Series 1, Appunto visto dal Duce, f.to Pièche, Roma 4 novembre 1942.

46 Rochat G. Le guerre italiane 1935-1943. Dall'impero d'Etiopia alla disfatta. Torino, 2008. 
particular resistance from the Italian civil society; they were adopted in silence and against the background of indifference. The racial laws led to the deportation (full or partial) or destruction of the Jewish communities in every country: it happened in France, Bulgaria, Hungary, Slovakia, Rumania (Transnistria) and Italy. In the Italian case, it appears clear that the will of Mussolini was above any other consideration and that the Duce wanted himself the legislation with all his force ${ }^{47}$. If we look at the consequences of the policy of 1938 for the Jewish communities, it was "to achieve a lowering of level of life and of the social and cultural characteristics of the Italian Jews" 48 . In the case of Rhodes, Italian complicity became full collaboration and support of an annihilation strategy, implemented through work that precedes and follows the deportation, preparing it and then "completing it" through the spoliation of the properties left on the island by the Jews.

It cannot be said, however, that the Italian racial laws just abolished the Jewish press or limited the Jewish presence in the professional fields; they disrupted the characteristics of a human group; it was forbidden to conduct business and economic activities, the Jews were forced to take their capitals out of the country, and they had to think about finding the way out in the new situation rather than continuing on the path of emancipation and participation. It was the creation of a group of "Helots" [Iloti], the prefiguration of a new collective exodus; this didn't mean the extermination by itself, however, but no anti-Jewish legislation of that time meant openly that.

When the extermination began in Lithuania and then in the Soviet forests, to be extended throughout Europe, touching finally Rhodes and Cos, the Jewish communities were deeply marked and weakened by the consequences of racism, by the departures, the migrations and, of course, by the war. If we take only peninsular Italy, between 1943 and 1945, the Italians carried out 1898 arrests of Jews, the Germans 2489, 312 were carried out in cooperation and 2314 have not been disclosed until now ${ }^{49}$.

According to J. Chapoutot, fascism tried to show to the world that Italy was a national community «united, rarely with problems of faith and confidence» ${ }^{50}$. Under the regime, Italians were supposed to find comfort, heroism, exceptionality, reassurance and the promise of an epic future: a rebirth and a regeneration of the humanity that should become "new" and free from the past era of liberalism and democracy. The progress and the "new man" would travel together in the future, hand in hand, thanks to the "Duce", the boss of the State. In reality, it was the Duce that wanted the discrimination of the Jews and later, during the war but before September 1943, their destruction. In the Italian society the people were not educated to hate, but were ready to reject any member, indicated by the Duce as "strange", anyone who didn't share the same principles and goals. Only the cruel reality of the war made, in some circumstances, the intervention of the military authorities possible, which could stop even Mussolini's decisions, not on account of "humanism", but owing to logical and practical considerations.

In Germany the idea of regeneration went further; eugenics opened up a way of replacing strangeness with something of European/German origins, which had to regener-

47 Sarfatti M. 1938. Le leggi contro gli ebrei e alcune considerazioni sulla normativa persecutoria // La legislazione antiebraica in Italia e in Europa. Roma, 1989.

48 Bidussa D. Il mito del bravo italiano. Milano, 1994. P.75.

49 Ibid. P. 64.

${ }^{50}$ Chapoutot J. Controllare e distruggere. Fascismo, nazismo e regimi autoritari in Europa (19181945). Torino, 2015. P. 148. 
ate the race and create new citizens, first of all fit for the military service. In this context one can share the assertion of Georges Bensoussan about the role that eugenics played in preparing the society for the next step, the destruction of the Jews ${ }^{51}$. The German bureaucracy follows these steps: designation of victims, confiscation of property, restriction of freedom and deportation ${ }^{52}$. One cannot forget, however, that in Italy the exclusion of the Jews from the social life took place 6-7 year prior to their mass murder. In Rhodes, a place where we can follow the whole history of the Jewish community from the issue of the racial laws until the deportation in 1944, we find a similarity with the Germany: the designation of the victims through the list, the restriction of their freedom, the deportation and then the confiscation of property. All four elements are present, but in a different order ${ }^{53}$.

Undoubtedly, September 8, 1943 changed a lot for Italy, producing a brand new military and political situation for the Apennine peninsula, but what happened later was not only the result of the Italian defeat. The Italian policy in the North and in the Dodecanese underwent an evolution, not a transformation. The foundations for the deportation and the destruction of the Italian and foreign Jews were already built in the past.

\section{References}

Aga Rossi E., Giusti M. Una guerra a parte. I militari italiani nei Balcani. 1940-1945. Bologna, Mulino Publ., 2011, 660 p.

Basciani A. Lillusione della modernità. Soveria Mandelli, Rubettino Publ., 2016, 489 p.

Bedeschi G. Fronte greco-albanese: c'ero anch'io. Milano, Mursia Publ., 1977, 684 p.

Benbassa E. Rodrigue A. Storia degli ebrei sefarditi. Torino, Einaudi Publ., 2004, pp. 279-280.

Ben Ghiat R. La cultura fascista. Bologna, Mulino Publ., 2004, 360 p.

Bensoussan G. Histoire de la Shoah. Paris, Presses Universitaires de France, 1997, 128 p.

Bidussa D. Il mito del bravo italiano. Milano, Il Saggiatore Publ., 1994, 110 p.

Browning Ch., with Matthäus Jürgen. The Origins of the Final Solution: The Evolution of Nazi Jewish Policy, September 1939 - March 1942. Lincoln, University of Nebraska Press, 2004, 615 p.

Capogreco C.S. I campi del Duce. L'internamento civile nell'Italia fascista (1940-1943). Torino, Einaudi Publ., 2004, 314 p.

Chapoutot J. Controllare e distruggere. Fascismo, nazismo e regimi autoritari in Europa (1918-1945). Torino, Einaudi Publ., 2015, 229 p.

Clementi M. Camicie Nere sull'Acropoli. L'occupazione italiana della Grecia. Roma, Derive Approdi Publ., 2013, 365 p.

Clementi M. Nuto Revelli, sozdatel' ital'janskoj ustnoj istorii. Pravo na imja. Biografika XX veka. Izbrannoe 2003-2012. St. Peterburg, Norma Publ., 2013, pp. 77-83. (In Russian)

Clementi M. Istoriia koroblia "Pentcho" i sud'ba ego passazhirov. Pravo na Imia. Biografika 20 veka, 11. St. Peterburg, Norma Publ., 2014, pp. 45-50. (In Russian)

Conti D. L’occupazione italiana dei Balcani. Crimini di guerra e mito della "brava gente". Roma, Odradek Publ., 2008, 288 p.

Conti D. Criminali di guerra italiani. Roma, Odradek., 2011, 344 p.

De Felice R. Storia degli ebrei italiani sotto il fascismo. Torino, Einaudi Publ., 1961, 695 p.

Dimension der Völkermords. Die Zahl der jüdischen Opfer des Nationalsozialismus. Hrst. von Benz. München, Wissenschaft Publ., 1991, 691 S.

Focardi F. Il cattivo tedesco e il bravo italiano. La rimozione delle colpe della seconda guerra mondiale. Roma, Laterza Publ., 2013, 288 p.

Fonzi P. La moneta nel grande spazio. La pianificazione nazionalsocialista dell'integrazione monetaria europea, 1939-1945, Milano, Unicopli Publ., 2011, 470 p.

51 Bensoussan G. Histoire de la Shoah. Paris, 1997. P.70.

52 Ibid. P.71.

${ }^{53}$ Gli ultimi ebrei di Rodi. Leggi razziali e deportazioni nel Dodecaneso italiano (1938-1948) / eds

M. Clementi, Ei. Toliou. Roma, 2015. P. 175-206. 
Fonzi P. Italian occupation of Crete during the Second World War. A view from below. Italian and the Secondo World War. Leiden, Brill Publ., 2017 (In press).

Gli ultimi ebrei di Rodi. Leggi razziali e deportazioni nel Dodecaneso italiano (1938-1948). Eds M. Clementi, Ei. Toliou. Roma, Derive Approdi Publ., 2015, 307 p.

Giustolisi F. L’armadio della vergogna. Roma, Beatedizioni Publ. , 2004, 380 p.

Hilberg R. Perpetrators Victims Bystanders. The Jewish catastrophe 1933-1945. New York, Harper Perennial Publ., 1993, 340 p.

Kertzer D. Il patto col diavolo. Milano, Rizzoli Publ., 2014, 556 p.

Kertzer D. I papi contro gli ebrei. Milano, BUR Publ., 2002, 365 p.

Lecoeur S. Mussolini Greek's Island. Fascism and the occupation of Syros in World War II. London, Tauris Publ., 2009, 260 p.

Longerich P. Heinrich Himmler: A life. Oxford, Oxford University Press, 2012, 1056 p.

Longenrich P. Goebbels. Torino, Einaudi Publ., 2016, 890 p.

Loukos Ch. Thanatoi apo peina sti Siro 1941-1944. Mithoi kai pragmatikotites. Deltio Kentrou tis Istorias tou Neoterou Ellinismou. Athina, Mnimi Eleutheriou Prevelaki Publ., 1998, pp. 30-45. (In Greek)

Matard-Bonucci M. L'Italia fascista e la persecuzione degli ebrei. Bologna, Il Mulino Publ., 2008, 514 p.

Moro R. La Chiesa e lo sterminio degli ebrei. Bologna, il Mulino Publ., 2009, 216 p.

Pera M. Ebrei di Salonicco. Appunti su "l'umanità italiana". Studi Storici, 2007, vol. 48, issue 2, pp. 341-359. Pezzetti M. Il libro della Shoah italiana. I racconti di chi è sopravvissuto. Torino, Einaudi Publ., 2009, 490 p.

Pizzuti A. Vite di carta. Roma, Donzelli Publ., 2010, 234 p.

Picciotto L. L'alba ci colse come un tradimento. Gli ebrei nel campo di Fossoli 1943-1944. Milano, Mondadori Publ., 2010, 294 p.

Picciotto L. Il libro della memoria. Gli ebrei deportati dall'Italia. Milano, Mursia Publ., 1991, 1008 p.

Revelli N. La guerra dei poveri. Torino, Einaudi Publ., 1962, 420 p.

Rochat G. Leopoli 1942-1943. Militari italiani dinanzi alla Shoah. La rassegna mensile di Israele, 2003, issue 2, pp. 387-394.

Rochat G. Le guerre italiane 1935-1943. Dall'impero d'Etiopia alla disfatta. Torino, Einaudi Publ., 2008, $469 \mathrm{p}$.

Rodogno D. Fascism's European Empire: Italian Occupation During the Second World War. Cambridge, Cambridge University Press, 2006, 562 p.

Rodogno D. Le nouvel ordre fasciste en Méditerranée, 1940-1943: présupposés idéologiques, visions et velléités. Revue d'histoire moderne et contemporaine, 2008, issue 55, 3, pp. 138-156.

Salomoni A. L'Unione Sovietica e la Shoah. Bologna, il Mulino Publ., 2007, 356 p.

Sarfatti M. La Shoah in Italia. La persecuzione degli ebrei sotto il fascismo. Torino, Einaudi Publ., 2005, 169 p.

Sarfatti M. L'evacuazione nel 1943 da Salonicco degli ultimi ebrei italiani e degli ebrei italiani 'provvisori': contesto, questioni e numeri. Eds by Ioly P. Zorattini, M. Luzzati, Firenze M. Sarfatti, S. Leo. Olchiki, Editor Publ., 2012, 276 p.

Sarfatti M. 1938. Le leggi contro gli ebrei e alcune considerazioni sulla normativa persecutoria. La legislazione antiebraica in Italia e in Europa. Roma, Camera dei Deputati Publ., 1989, pp. 13-18.

Sarfatti M. Tra uccisione e protezione. I rifugiati ebrei in Kosovo nel marzo 1942 e le autorità tedesche, italiane e albanesi. La rassegna mensile di Israel, 2010, issue 3, pp. 223-242.

Steinberg J. All or nothing. The Axis and the Holocaust 1941-1943, New York, Routledge Publ., 1990, 320 p.

Snyder T. Black Earth: The Holocaust as History and Warning. London, Penguin Publ., 2015, 462 p.

Yahil L. The Holocaust. The Fate of European Jewry. Oxford, Oxford University Press, 1990, 808 p.

Zuccotti S. Under his very windows: the Vatican and the Holocaust in Italy. New Haven, Yale University Press, 2000, $436 \mathrm{p}$. 